\title{
Farklı gölgeleme durumlarının fotovoltaik panel karakteristiği üzerine etkisi
}

\author{
Effect of different shading situations on photovoltaic panel characteristics
}

\author{
Eda Feyza AKYÜREK ${ }^{1, a}$, Kadir GELIŞS²,b, Mehmet YOLADI ${ }^{1, c}$ \\ ${ }^{1}$ Erzurum Teknik Üniversitesi, Mühendislik ve Mimarlık Fakültesi, Makine Mühendisliği Bölümü, 25050, Erzurum \\ ${ }^{2}$ Bolu Abant İzzet Baysal Üniversitesi, Mühendislik Fakültesi, Makine Mühendisliği Bölümü, 14030, Bolu
}

• Geliş tarihi / Received: 07.07.2020 • • Düzeltilerek geliş tarihi / Received in revised form: 01.12.2020 • Kabul tarihi / Accepted: 10.12 .2020

\begin{abstract}
Öz
Birçok gelişmiş ülkenin üzerinde çalışmalar yaptığı konulardan biri olan fotovoltaik sistemler, güneş enerjisinden elektrik enerjisi elde etmek için kullanılır. Fotovoltaik sistemler enerji ihtiyacını karşılamak için en güvenilir ve en hesaplı alternatiflerden biri olarak ortaya çıkmıştır. Bu enerji ihtiyacı karşılama durumunda zamana bağlı olarak kısmi gölgelenme gibi durumların incelenmesi, enerjiyi karşılama açısından hayati önem taşımaktadır. Gölgeleme durumu, elde edilen gücün önemli ölçüde azalmasına neden olmaktadır. Gölgeleme oranı arttıkça verim azalmaktadır. Dolayısıyla farklı şartlar için, gölgeleme durumunun elde edilen güç üzerindeki etkisinin araştırılması gerekmektedir. Bu çalışma laboratuvar ortamında solar simülatör kullanılarak yapılmıştır. Yapay ışık kaynağı ve panel arasındaki uzaklık $0.8 \mathrm{~m}$ ve $1.4 \mathrm{~m}$, açı ise $0^{\circ}, 20^{\circ}$ ve $40^{\circ}$ olacak şekilde ayarlanmıştır. Hücrelerde gölgeleme olmaması durumu ile $1 / 36$ ve $2 / 36$ gölgeleme durumu, panel karakteristiği ve maksimum gücün değişimi açısından karşılaştırılmıştır. Sonuçlar yapay ışık kaynağı ve panel arasındaki mesafe ve açı arttıkça elde edilen maksimum gücün azaldığını göstermiştir.
\end{abstract}

Anahtar kelimeler: Fotovoltaik panel, Fotovoltaik sistem, Kısmi gölgeleme, Maksimum güç

\begin{abstract}
Photovoltaic systems, which is one of the subjects that many developed countries are working on, are used to obtain electrical energy from solar energy. Photovoltaic systems have emerged as one of the most reliable and affordable alternatives to meet energy needs. In case of meeting this energy need, examining the conditions such as partial shading depending on the time is vital for meeting the energy. The shading situation causes the power obtained to decrease significantly. As the shading rate increases, the efficiency decreases. Therefore, for different conditions, the effect of the shading situation on the power obtained must be investigated. This study was done in a laboratory environment by using solar simulator. The distance between the artificial light source and the panel is set at $0.8 \mathrm{~m}$ and $1.4 \mathrm{~m}$, and the angle is $0^{\circ}, 20^{\circ}$ and $40^{\circ}$. In case of shading to the all cells and shading to 1/36, 2/36 cells, in terms of panel characteristic and change of maximum power are compared. The results showed that the maximum power obtained decreases as the distance and angle between the artificial light source and the panel increases.
\end{abstract}

Keywords: Photovoltaic panel, Photovoltaic system, Partial shading, Maximum power

\footnotetext{
*b Kadir GELiş; kadirgelis@ibu.edu.tr, Tel: (0374) 25410 00/4938, orcid.org/0000-0001-8612-2233

${ }^{\mathrm{a}}$ orcid.org/0000-0003-4007-6846 $\quad{ }^{\mathrm{c}}$ orcid.org/0000-0002-4729-0768
} 


\section{Giriş}

Enerji, ekonomik kalkınma ve günlük yaşam için en önemli kaynaklardan biridir. Ancak enerjimizin çoğunluğu, tükenebilir fosil enerji kaynakları olan; kömür, petrol, doğalgaz gibi yakıtlar kullanılarak karşılanmaktadır. Gelecekte bu kaynakların tükenebileceği ve kullanılabilir kaynakların azalması beklenen bir sonuçtur. Ayrica fosil kökenli yakıtlar karbondioksit üretimi ve sera gazı etkisi gibi çevresel sorunlara neden olmaktadır. $\mathrm{Bu}$ yüzden güneş enerjisi, rüzgâr enerjisi ve jeotermal enerji gibi yenilenebilir enerji kaynaklarma yönelmeli ve bu kaynakların kullanılabilirliğini artırmaya yönelik çalışmalar yapilması gerekmektedir. Güneş enerjisi uygulamaları en tercih edilen yenilenebilir enerji kaynaklarından birisidir. Tüm yenilenebilir enerji kaynakları arasında en bol, tükenmez, temiz ve çevre dostu kaynaktır. Güneşten gelen enerji, hidrojen çekirdeklerinin birleşerek helyuma dönüşmesi sırasında kütle kaybının karşılığı olarak ortaya çıkmaktadır. Güneşten elde edilen enerjinin maksimum değere ulaşabilmesi çeşitli parametrelere bağlıdır. Bunlar arasında en önemli olanlardan birisi gökyüzü açıklığıdır. Gölge durumunda fotovoltaik sistemlerden elde edilen güç önemli miktarda azalmaktadır. Fotovoltaik sistemler, güneş enerjisinden elektrik üretmek için kullanılan sistemlerdir. Fotovoltaik sistemler sayesinde güneş enerjisi doğrudan elektrik enerjisine dönüştürülebilmektedir. Farklı sebeplerle fotovoltaik paneller üzerine gölgeleme durumu söz konusu olabilir, gökyüzünün kapalı olduğu zamanlarda gölgeleme durumunda 1 şık geçişi gerçekleşmez ve bu yüzden az miktarda enerji üretimi gerçekleşmektedir. Literatürde gölgeleme konusunu esas alan bazı çalışmalar aşağıda özetlenmiştir.

Araştırmacılar (Pareek vd., 2017), fotovoltaik sistemlerde gölgeleme durumunda elde edilen gücün ara bağlantıların farklı yapılması durumlarını incelemişlerdir. Önerilen ara bağlantılar, modüller arasındaki ara bağlantı sayısının ve kayıpların optimizasyonu gerçekleştirilmiştir. Bu bağlantıların gölgeleme konumuna bağlı olduğu sonucuna varılmıştır. Araştırmacılar (Kaced vd., 2017), kısmi gölgelemede PV sistem üzerine BAT algoritmasıyla global optimizasyon uygulanarak MATLAB-Simulink programı kullanılmış ve deneysel sonuçlarla karşılaştırılmıştır. Yapılan çalışmada elde edilen algoritma ile deneysel veriler arasında büyük bir uyum sağlanmıştır. Araştırmacılar (Zhang vd., 2018), gölgeleme üzerine yapılan çalışmaların \%20 si Çin, \%10’u
Yunanistan ve \%10'u İsviçre gerçekleştiğini iddia etmiş ve araştırmaların çoğunluğunun panel konumu değiştirilerek uygulanan çalışmalar olduğuna vurgu yapılmıştır. Araştırmacılar (Sai Krishna ve Moger, 2019), tarafindan k1smi gölgeleme koşulları altında maksimum gücü artırmaya yönelik çalışılmıştır. Dinamik ve statik yeniden yapılandırma stratejileri belirlenmiştir. Dinamik yapılandırma sistemlerinin maliyetli olduğu belirtilmiştir. Statik çalışmanın stabil çalışma için en iyi alternatif olduğu belirtilmektedir. PV konfigürasyonu yeniden tasarlanması pazarlama hedefi ve gerekli diğer maliyet açısından zorluklar içerdiği gösterilmiştir. Araştırmacılar (Yin ve Babu, 2018), tarafindan MATLAB-Simulink programı kullanılarak tek ve iki diyotlu PV hücresi üzerinde kısmi ve normal gölgeleme etkisi incelenmiştir. PV modül performansı çevresel değişkenlerden, özellikle sıcaklık ve 1şınımdan etkilenmektedir. Kısmi gölgeleme 1şınımı azaltarak sisteme verilen güç birçok pik noktadan oluştuğu belirtilmektedir. Oluşturulan matematiksel model sonucunda her modelin avantajları ve dezavantajları, bilinmeyen parametrelerin sayısı, doğruluğu ve hesaplama süresi karşılaştırılmıştır. Her iki modelin sonuçları teorik öngörü ile eşleşmiştir. Araştırmacılar (Zhu vd., 2018), tarafindan bir bina üzerine entegre edilen PV sistemin güç çıktısını tahmin eden bir matematiksel model oluşturulmuştur. Gölgeleme oranının fotoakım ve serilerin direnci incelenmiştir. Gölgelenen PV sistemin elektrik performansı simüle edilmiştir. Yapılan matematiksel modeller deneylerle doğrulanmıştır. Gölge modülün kısa kenarına paralel ve uzun kenarına paralel olarak iki şekilde uygulanmıştır. Kisa kenara paralel uygulamak daha fazla olumsuz etki ortaya çıkarmıştır. Araştırmacılar (AshouriZadeh vd., 2018), kısmi gölgeleme koşulları altında PV sistemden maksimumum güç elde etmek için yeni bir teknik geliştirmiştir. PV hücrelerinin seri ve paralel konfigürasyonunun sağlandığı maksimum güç noktasını belirlemek için oluşturulan yeni teknik ek ölçüm veya donanım değişikliği içermemektedir. Yazılım olarak yapılan değişiklikle algoritmanın dinamik tepkisi simülasyonlar ile incelenmiştir. Kısmi, normal ve tam gölgeleme durumlarında gösterdiği performans eskisine göre oldukça etkili olduğu gösterilmiştir. Araştırmacılar (Chaibi vd., 2019), tarafından PV sistemlerde elektriksel arıza ve kısmi gölgelemeleri teşhis etmek için basit ve etkili bir yaklaşım gerçekleştirilmiştir. Önerilen yöntem üç göstergenin analizine dayanmaktadır. Bu yaklaşım deneysel olarak doğrulanmıştır. Bu üç gösterge voltaj, akım ve güç göstergeleridir. Ölçülen ve öngörülen maksimum güç noktasının 
koordinatları; akım, voltaj ve güç göstergelerinin hesaplanmasına izin vermektedir. Bu üç gösterge elektriksel değişkenlere bağlıdır. Araştırmacılar (Sánchez Reinoso vd., 2013), tarafindan fotovoltaik sistemlerin dinamik gölgeleme durum simülasyonu analiz edilmiştir. Sonuçlar çalışma koşulları altında merkezi invertör kullanarak kısmi gölgeleme ile en verimli bağlantı şeması elde edilmiştir. Optimizasyon algoritması kullanmadan, merkezi invertör ile bu sonuçlara ulaşılabilmektedir. Bu sonuçlar büyük fotovoltaik tesislerde maliyeti düşürecektir. Araştırmacılar (Bayrak vd., 2017), tarafindan PV panel üzerinde kısmi gölgeleme durumunda enerji ve ekserji verimliliği üzerine etkileri deneysel olarak çalışılmıştır. Üç farklı gölgeleme pozisyonunda yatay ve dikey konumda sonuçlar gözlemlenmiştir. En yüksek güç kaybı durum-2 (yatay) tam gölgeleme durumunda elde edilmiştir. $75 \mathrm{~W}$ gücündeki fotovoltaik panellerin elektriksel ve termodinamik analizi incelenmiştir. Yatay gölgelemede akım 3.31A 'den 0.14A 'e düşerek maksimum güç azalması elde edilmiştir. Sicaklık artış1 durumunda güneş radyasyonu değeri maksimum olduğunda hem enerji hem de ekserji verimliliği düşmektedir. Araştırmacılar (Ramli ve Salam, 2019), tarafından PV panelde kısmi gölgeleme durumunda sistem için DC güç iyileştirici (DCPO) kullanarak sistem performans1 incelenmiştir. Ayrıca DC güç iyileştiriciye sahip PV sistemdeki davranışı tahmin eden analitik bir yöntem geliştirilmiştir. Bu sayede sistemin enerji kazancının \%2,8'den \%6,4'e yükseldiği gösterilmiştir. Araştırmacılar (Wang vd., 2017), tarafindan bina üzerindeki PV modülün elektrik üretimi ve çatının 1sıl performansının gölgeleme durumunda nasıl etkilendiğini öğrenmek için basit fiziksel ve matematiksel modeller oluşturulmuştur. $\mathrm{Bu}$ modeller deneysel sistemlerden elde edilen sonuçlarla karşılaştırılmış ve uyum içerisinde olduğu gözlemlenmiştir. PV panelin soğutma yükü ve 1sı kazancı, 1sıl yükleme artışıyla zayıflamışıtır.

Literatürden de anlaşılacağı üzere gölgeleme konusu fotovoltaik panellerin performansinı etkileyen önemli bir konudur. Uygulamada fotovoltaik hücrelerle dolu bir tarla, bu tarlanın belli bir konumunun gölgeleme etkisi altında kalması durumunun enerjinin elde edilmesini nasıl etkilediğini incelemek oldukça güçtür. Bunun yerine benzetim ve modelleme kullanılarak laboratuvar ölçekli gölgeleme yapılabilir. Bu yaklaşımla maliyet düşürülürken, büyük sistemlerin kurulumu esnasinda gölgeleme konusunun farklı durumları incelenmiş ve modelleme yapmak isteyen araştırmacılara bir yaklaşım sunulmuştur. Bu çalışmada deney setinde yer alan ve birbirine paralel olarak bağlanmış iki modül için farklı gölgeleme durumlarında performansın nasıl etkilendiği hakkında deneysel bir veri seti oluşturulmuş ve bu veri setinden elde edilen sonuçlar için çıkarımlarda bulunulmuştur.

\section{Materyal ve metot}

Deneyler Erzurum Teknik Üniversitesi laboratuvarında bulunan Solar Simülatör vasıtasıyla gerçekleştirilmiştir. Solar Simülatörün fotoğrafı Şekil 1'de verilmiştir.

Deney setinde güneş modülü, 1şık şiddeti sensörü, sicaklık sensörü, tutturma bloğu, ölçme ünitesi, reosta, eğim açısı ölçer gibi elemanlar bulunmaktadır. Deney setinde fotovoltaik paneller üzerine düşen 1 şınım yapay bir ışık kaynağı olup, yapay ışık kaynağı ile panel arasındaki açık $0^{\circ}$ den $90^{\circ}$ ye kadar değiştirilebilmektedir. Işınım yoğunluğu piranometre vasıtasıyla ölçülmektedir. Panel alt yüzeyinde panel sıcaklığının ölçüldüğü bir sıcaklık sensörü bulunmaktadır. Polarizasyon eğrilerinin elde edilmesi için direnci $0 \Omega$ ile $10 \Omega$ arasında değişebilen bir reosta kullanılmıştır. Akım, voltaj, 1şınım yoğunluğu ve sicaklık verilerinin toplandığı bir ölçüm ünitesi mevcuttur. Veriler anlık olarak ölçüm ünitesi ekranından izlenebileceği gibi bir yazılım vasıtasıyla bilgisayara da aktarılabilmektedir. Sistemde iki adet seri ya da paralel bağlanabilen panel bulunmaktadır. Sistem çıktıları olan akım, gerilim ve 1şınım yoğunluğu veri toplama ünitesi ekranindan anlık olarak okunabilmektedir. Sistemde bulunan fotovoltaik panellerin bir tanesinde 4 sütun ve 9 satır olmak üzere toplamda 36 adet monokristal hücre bulunmaktadır. Fotovoltaik modül toplam yüzey alanı 1.114 $\mathrm{m}^{2}$ 'dir. Deneyler 3 farklı gölgeleme durumu için yapılmıştır. Farklı gölgeleme durumları Şekil 2'de, gölgeleme durumlarının açıklamaları ise Tablo 1 'de verilmiştir. Deneyler esnasında öncelikli olarak yapay 1 şı kaynağ mesafe 0,8 m olarak ayarlanmış, değişen $0^{\circ}, 20^{\circ}$ ve $40^{\circ}$ için sistem direnci değiştirilerek voltaj ve akım değerleri elde edilmiştir. Her bir durum için gölgeleme durumları değiştirilerek veriler tekrar kaydedilmiştir. Aynı deneyler 1,4 m mesafe ve $0^{\circ}, 20^{\circ}, 40^{\circ}$ ve farklı gölgeleme durumları için de tekrarlanmıştır. Elde edilen bütün farklı durumlar için polarizasyon eğrileri oluşturulmuş ve farklı durumlar için polarizasyon eğrilerinin maksimum güç değerleri değişmesine rağmen eğilimlerin benzer olduğu görülmüştür. $\mathrm{Bu}$ sebeple temel olarak seçilen $0,8 \mathrm{~m}$ mesafe ve $0^{\circ}$ açı için polarizasyon eğrileri verilmiş, diğer durumlar için 
ise sadece maksimum güç değerleri verilerek, bu değerler üzerinden çıkarımlarda bulunulmuştur.

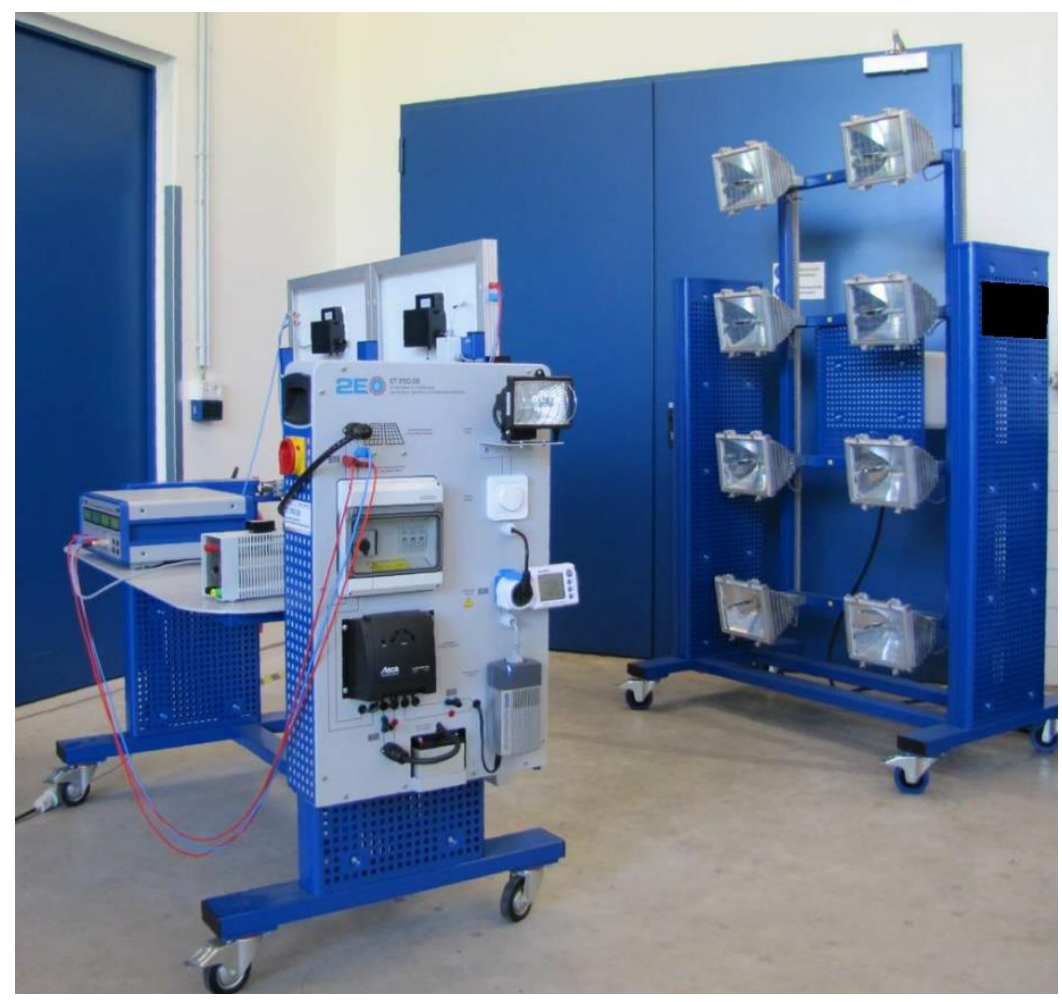

Şekil 1. Deneylerde kullanılan solar simülatörün fotoğrafi

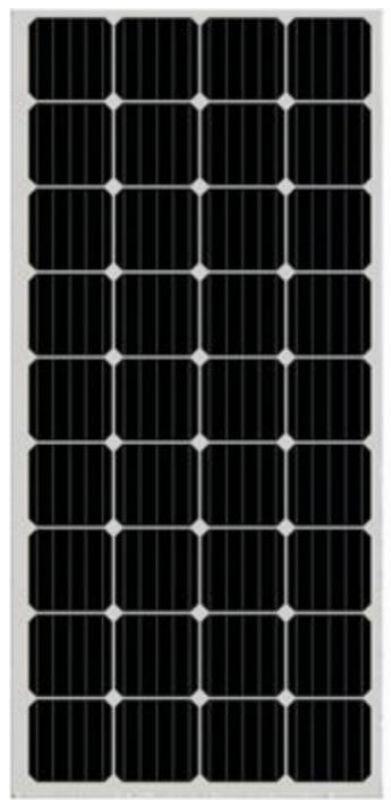

( Durum I )

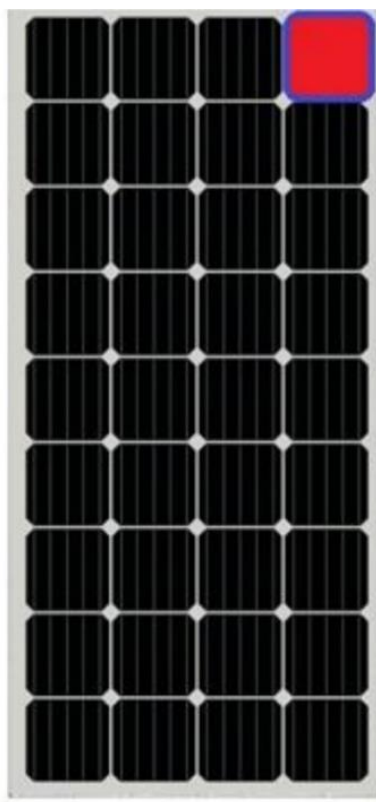

( Durum II )

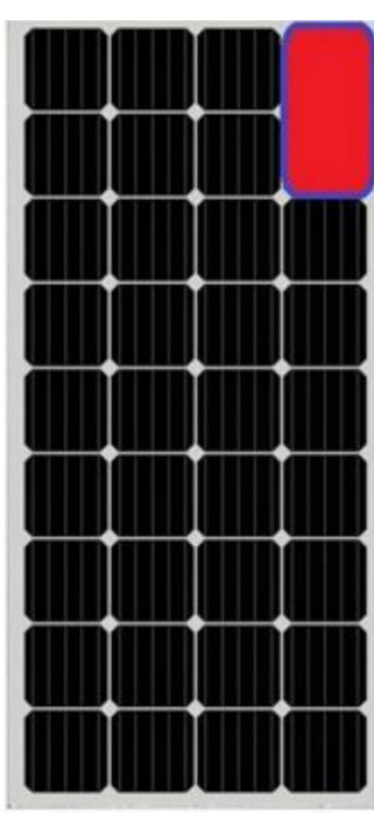

( Durum III )

Şekil 2. Farklı gölgeleme durumları

Tablo 1. Farklı Gölgeleme durumları için açılama

\begin{tabular}{ll}
\hline Durum & Açıklama \\
\hline Durum I & 36 hücrenin tamamı açik (Gölgeleme yok) \\
Durum II & 1 hücre gölgeleme etkisi altında 35 hücre açık \\
Durum III & 2 hücre gölgeleme etkisi altında 34 hücre açık \\
\hline
\end{tabular}


Birinci durumda 36 hücrenin tamamı açık, ikinci durumda $1 / 36$ hücre açık ve üçüncü durumda $2 / 36$ hücre kapatılarak gölgeleme durumları çalışılmıştır.

\section{Bulgular}

Yapılan çalışmada yapay 1 şı kaynağ 1 ve panel arasındaki uzaklık $0,8 \mathrm{~m}$ ve $1,4 \mathrm{~m}$, açı ise $0^{\circ}, 20^{\circ}$ ve $40^{\circ}$ olacak şekilde ayarlanmıştır. Hücrelerin tamamında gölgeleme olmaması durumu, $1 / 36$ ve 2/36 gölgeleme durumunda panel karakteristiği ve maksimum gücün değişimi incelenmiştir.
Şekil 3 ve Şekil 4'te yapay 1şık kaynağ 1 ve panel arasındaki mesafenin $0,8 \mathrm{~m}$, açının ise $0^{\circ}$ olduğu durum için Akım-Gerilim, Güç-Gerilim grafikleri verilmiştir. Deneysel parametrelerin tamamında aynı grafik eğilimleri elde edildiği için; parametrelerin tamaminda benzer grafiklerin türetilmesi yerine farklı durumlar için maksimum güç değerlerini veren grafikler oluşturulmuştur. Farklı parametreler için elde edilen maksimum güç değerleri Şekil 5, Şekil 6 ve Şekil 7'de verilmiştir. Şekil 3 ve Şekil 4'ten de anlaşıldığı üzere Durum II ve Durum III kısmi gölgeleme durumlarında maksimum güç çıktısı azalmıştır. Her 3 durum içinde açık devre voltaj1 18.3 V'tur.

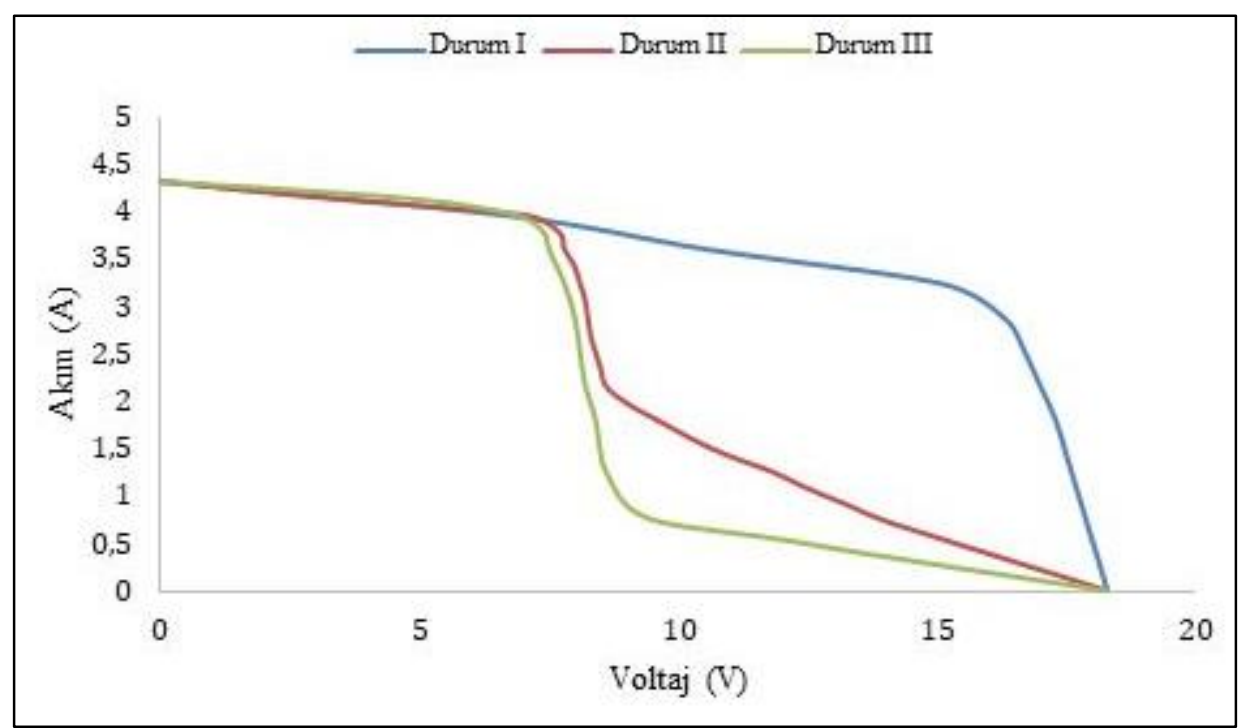

Şekil 3. Durum I için Akım-Voltaj grafiği $\left(\right.$ mesafe $=0.8 \mathrm{~m}$, açı $\left.=0^{\circ}\right)$

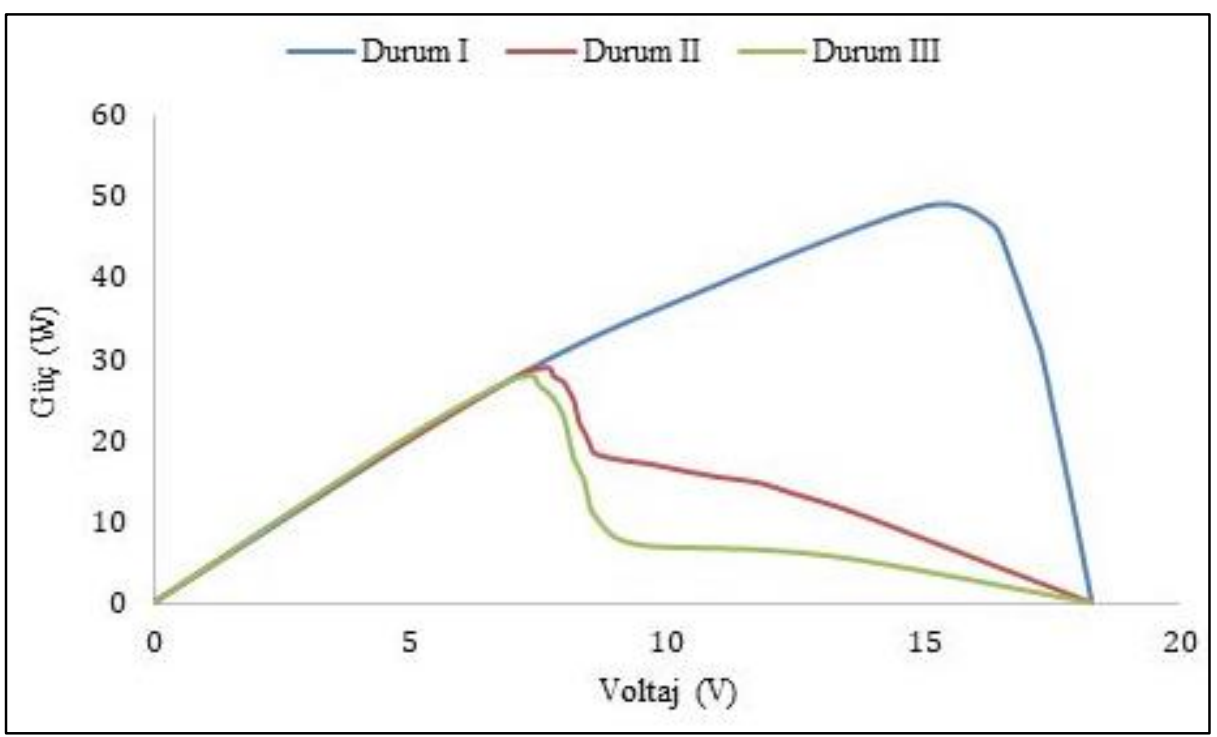

Şekil 4. Durum I için Güç-Voltaj grafiği (mesafe $=0,8 \mathrm{~m}$, açı $=0^{\circ}$ )

Şekil 5'te panel üzerine hiç gölgeleme yapılmamış, yapay 1şık kaynağ 1 ve panel arasındaki mesafenin $0,8 \mathrm{~m}, 1,4 \mathrm{~m}$; açının ise $0^{\circ}, 20^{\circ}$ ve $40^{\circ}$ için maksimum güç değerleri verilmiştir. Açının $0^{\circ}$ olduğu, mesafenin 0.8 m'den 1.4 m'ye çıktığ durum için maksimum güç değeri $49.9 \mathrm{~W}$ ' dan 
37W'a düşmüş ve $\% 25,85$ azalma göstermiştir. Açının $20^{\circ}$ olduğu, mesafenin 0.8 m'den 1.4 m'ye çıktığı durum için maksimum güç değeri 48W'dan 29W'a düşmüş ve \%39,8 azalma göstermiştir. Açının $40^{\circ}$ olduğu, mesafenin 0.8 m'den 1.4 m'ye çıktığı durum için maksimum güç değeri 43W'dan
22W'a düşmüş ve $\% 48,84$ azalma göstermiştir. Mesafenin $0,8 \mathrm{~m}$ olduğu durumda açı $0^{\circ}$ iken maksimum gücün $49.9 \mathrm{~W}, 20^{\circ}$ iken $48 \mathrm{~W}, 40^{\circ}$ iken $43 \mathrm{~W}$ olduğu gözlemlenmiştir. Açının $0^{\circ}$ den $20^{\circ}$ ye çıkması ile güç değeri $\% 3,8$ kadar, $0^{\circ}$ den $40^{\circ}$ ye çıkmas $1 \% 13,83 \mathrm{kadar}, 20^{\circ}$ den $40^{\circ}$ ye çıkması ile \% 10,42 kadar azalmıştır.

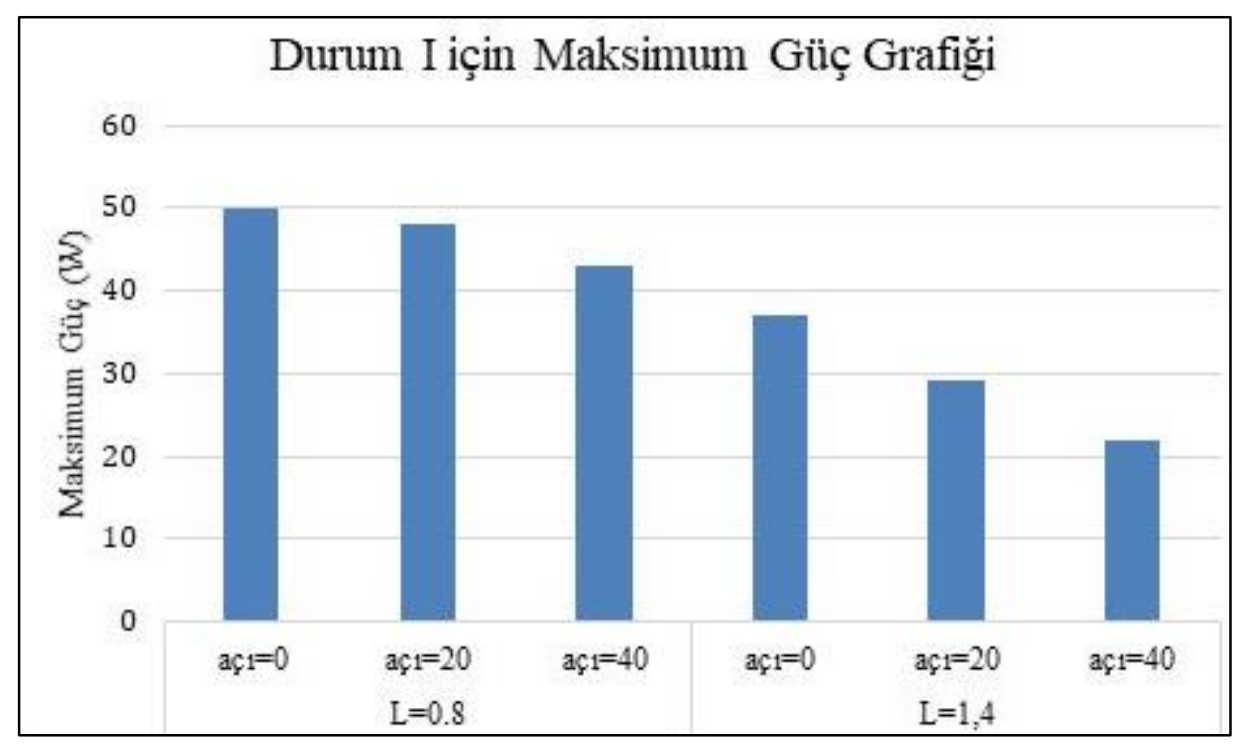

Şekil 5. Durum I için maksimum güç grafiği

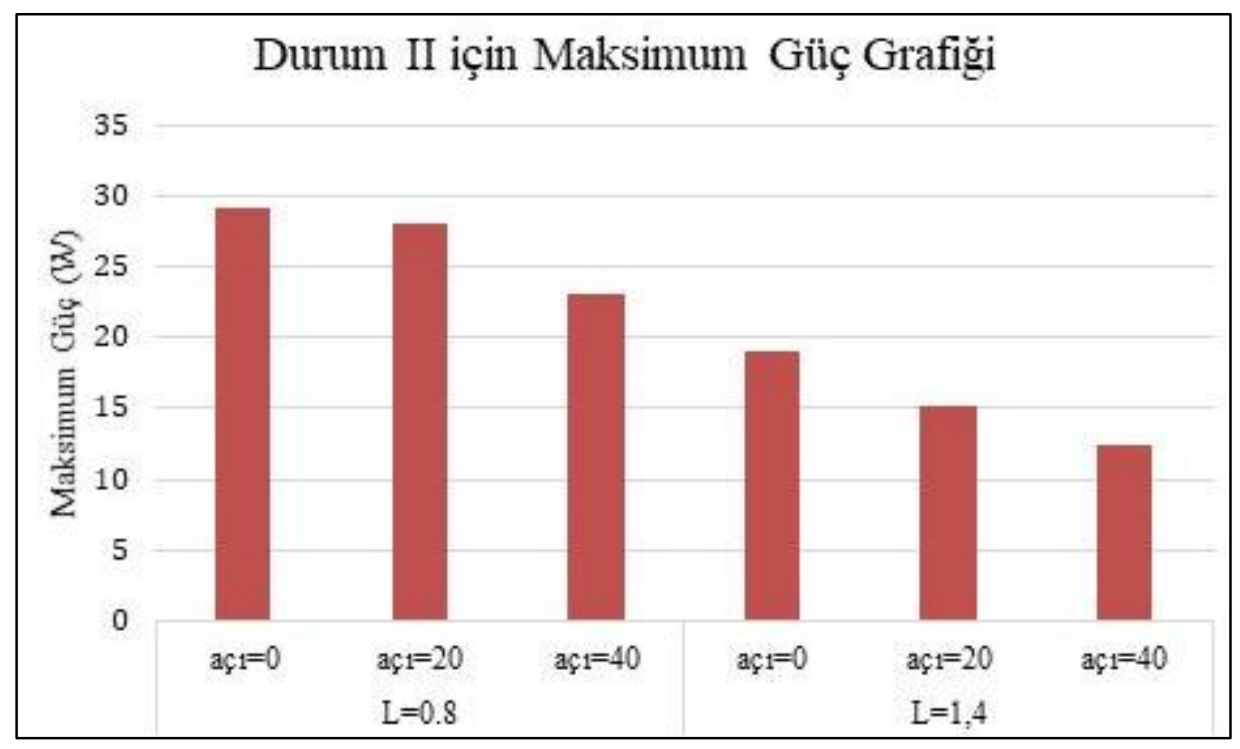

Şekil 6. Durum II için maksimum güç grafiği

Şekil 6'da panel üzerine 1/36 kısmi gölgeleme yapılmış, yapay 1 şı kaynağı ve panel arasındaki mesafenin $0.8 \mathrm{~m}, 1.4 \mathrm{~m}$; açının ise $0^{\circ}, 20^{\circ}$ ve $40^{\circ}$ olduğu durumlarda maksimum güç değerleri verilmiştir. Açının $0^{\circ}$ olduğu, mesafenin $0.8 \mathrm{~m}$ 'den 1.4 m'ye arttığı durum için maksimum güç değeri 29.1W'dan 19W'a düşmüş ve $\% 34,71$ azalma göstermiştir. Açının $20^{\circ}$ olduğu, mesafenin 0.8 m'den 1.4 m'ye arttığ 1 durum için maksimum güç değeri $28 \mathrm{~W}$ 'dan $15.2 \mathrm{~W}$ 'a düşmüş ve $\% 45,71$ azalma göstermiştir. Açının $40^{\circ}$ olduğu, mesafenin 0.8 m'den 1.4 m'ye arttı̆ ${ }_{1}$ durum için maksimum güç değeri $23 \mathrm{~W}$ 'dan $12.5 \mathrm{~W}$ 'a düşmüş ve $\% 45,65$ azalma göstermiştir. Mesafenin $0.8 \mathrm{~m}$ olduğu durumda açı $0^{\circ}$ iken maksimum güç $29.1 \mathrm{~W}, 20^{\circ}$ iken maksimum güç $28 \mathrm{~W}, 40^{\circ}$ iken maksimum güç $23 \mathrm{~W}$ olduğu gözlemlenmiştir. Açının $0^{\circ}$ den $20^{\circ}$ ye çıkması ile güç değeri $\% 3,78 \mathrm{kadar}, 0^{\circ}$ den $40^{\circ}$ ye çıkması $\% 17,75$ kadar, $20^{\circ}$ den $40^{\circ}$ ye çıkması ile $\% 17,86$ kadar azalmıştır. 


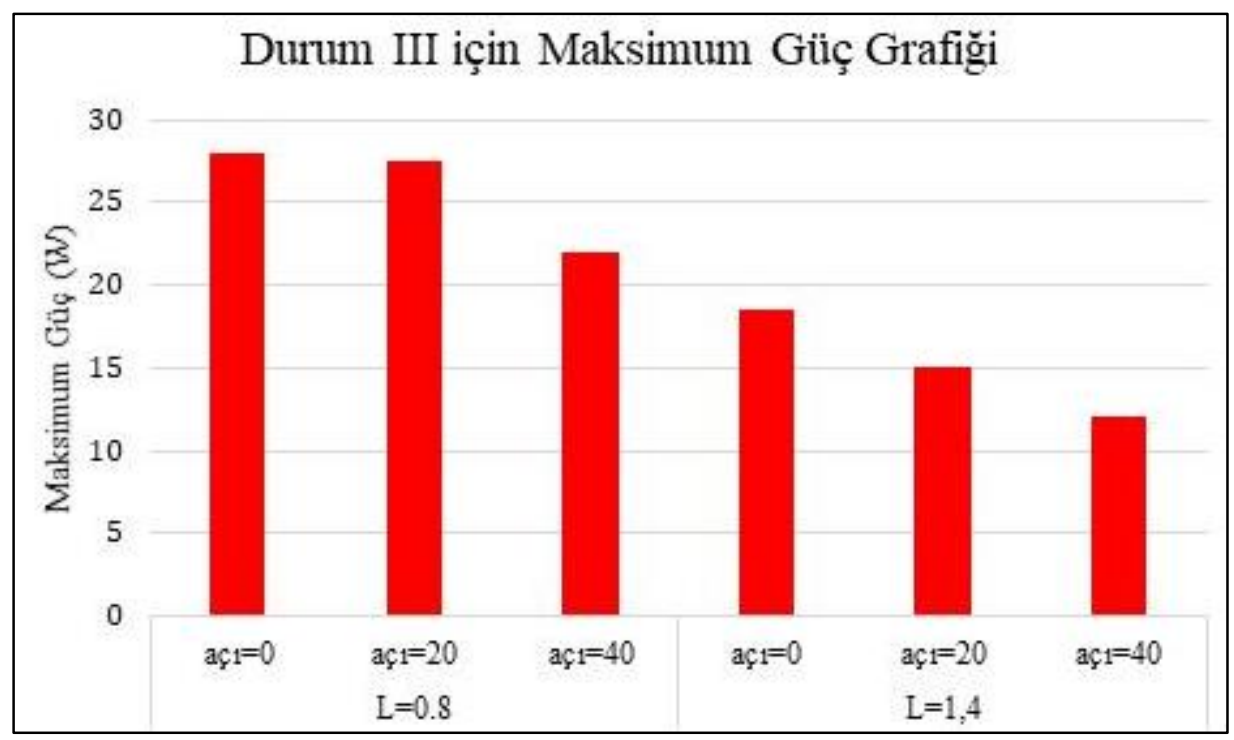

Şekil 7. Durum III için maksimum güç grafiği

Şekil 7'de panel üzerine 2/36 kısmi gölgeleme yapılmış, yapay 1 şık kaynağı ve panel arasındaki mesafenin $0.8 \mathrm{~m}, 1.4 \mathrm{~m}$; açının ise $0^{\circ}, 20^{\circ}$ ve $40^{\circ}$ olduğu durumlarda maksimum güç değerleri verilmiştir. Açının $0^{\circ}$ olduğu, mesafenin 0.8 m'den $1.4 \mathrm{~m}$ 'ye arttığ durum için maksimum güç değeri 27.9 W'dan 18.5 W'a ye düşmüș ve $\% 33,69$ azalma göstermiştir. Açının $20^{\circ}$ olduğu, mesafenin $0.8 \mathrm{~m}$ 'den $1.4 \mathrm{~m}$ 'ye çıktığı durum için maksimum güç değeri $27.5 \mathrm{~W}$ 'dan $15 \mathrm{~W}$ 'a düşmüş ve $\% 45,45$ azalma göstermiştir. Açının $40^{\circ}$ olduğu, mesafenin $0.8 \mathrm{~m}$ 'den $1.4 \mathrm{~m}$ 'ye arttığ durum için maksimum güç değeri $22 \mathrm{~W}$ 'dan $12 \mathrm{~W}$ 'a düşmüş ve $\% 45,45$ azalma göstermiştir. Mesafenin $0.8 \mathrm{~m}$ olduğu durumda açı $0^{\circ}$ iken maksimum güç $27.9 \mathrm{~W}, 20^{\circ}$ iken maksimum güç $27.5 \mathrm{~W}, 40^{\circ}$ iken maksimum güç $22 \mathrm{~W}$ olarak belirlenmiştir. Açının $0^{\circ}$ den $20^{\circ}$ ye çıkması ile güç değeri $\% 1.43 \mathrm{kadar}, 0^{\circ}$ den $40^{\circ}$ ye çıkması $\% 21,15$ kadar, $20^{\circ}$ den $40^{\circ}$ ye çıkması ile \%20 kadar azalmıştır.

Kaynak ve PV panel arasındaki mesafenin $0.8 \mathrm{~m}$ 'den $1.4 \mathrm{~m}$ ' ye çıاkması ile sistemden elde edilen güç büyük oranda azalmıştır. Bu durum güneş ile fotovoltaik paneller arasındaki fiziksel ilişki ile açıklanabilir. Güneşten elde edilen enerjinin büyük miktarı; atmosferden, bulutlardan, yerden yansıması ve soğurulması sonucu kaybedilmektedir. Özellikle güneş enerjisinin yoğunluğu atmosfer kalınlığına bağlı olarak azalmaktadır. Atmosferde bulunan taneciklerle etkileşimde olan güneş radyasyonu, geçişi sirasinda enerjisini transfer ederek ilerlemektedir. Hava koşullarındaki değişiklik bu orantıyı daha da artırmaktadır. Ayrıca panel açısı güneş enerjisinin geliş açısı ve panel konumunun normali arasındaki açının kosinisü ile orantılı olarak değişmektedir.
Güneş ve fotovoltaik sistem arasındaki ilişkiye benzer bir şekilde yapay 1şık kaynağı ve panel arasındaki açı ve mesafe değişimi kayıpların artışına neden olmakta ve maksimum güç azalmaktadır.

\section{Tartışma ve sonuçlar}

Deneyler Erzurum Teknik Üniversitesi Mühendislik Fakültesi Laboratuvarında bulunan solar simülatör kullanılarak yapılmıştır. Bu çalışmada uygulamada sıkça karşılaşılan güneş panellerinin k1smi gölgelenmesi durumu için deneysel bir çalışma yürütülmüştür. Fotovoltaik panellerin kısmi gölgelenmesi durumunun daha iyi anlaşılması ile güneş enerji santrallerinin projelendirilmesi konusuna katk1 sağlanacağ 1 düşünülmektedir. Çalışma sonucunda elde edilen bazı önemli sonuçlar aşağıdaki gibi sıralanabilir:

- Yapay ışık kaynağı ve panel arasındaki mesafe arttı̆ğında elde edilen maksimum güç azalmaktadir.

- Yapay 1şık kaynağ 1 ve panel arasındaki açı arttıkça elde edilen maksimum güç azalmaktadır.

- Yapay ışık kaynağı ve panel arasındaki mesafe $0,8 \mathrm{~m}$ ve açılar $0^{\circ}, 20^{\circ}, 40^{\circ}$ derece olmas 1 durumunda panelden elde edilen maksimum güç değerleri sırasıyla 49.9, 48, $43 \mathrm{~W}$ iken mesafe $1,4 \mathrm{~m}$ ve açılar $0^{\circ}, 20^{\circ}, 40^{\circ}$ derece olmas1 durumunda panelden elde edilen maksimum güç değerleri sırasıyla 37, 29, 22 W' tır.

- Mesafenin 0,8 $\mathrm{m}$ açının $0^{\circ}$ olduğu durum için sistemden elde edilen maksimum güç değeri $49.9 \mathrm{~W}$ iken, mesafenin $1,4 \mathrm{~m}$ açının $40^{\circ}$ 
olduğu durum için elde edilen maksimum güç değeri $22 \mathrm{~W}$ olmuştur. Bu iki farklı durum neticesinde elde edilen güç değerleri birbiri ile kıyaslandığında gölgelemenin güç üretimi üzerine dikkate değer bir etki oluşturduğu sonucuna varılmıştır.

- Maksimum güç çıktıları sırasıyla Durum I, Durum II ve Durum III'te oluşmuştur.

- $0,8 \mathrm{~m}$ mesafe için açının $0^{\circ}$ den $20^{\circ}$ çıkmas1 durumunda maksimum güç $\% 3,8,0^{\circ}$ den $40^{\circ}$ çıkması durumunda $\% 13,83,20^{\circ}$ den $40^{\circ}$ ye çıkması durumunda ise $\% 10,42$ azalmıştır.

- $\quad 1,4 \mathrm{~m}$ mesafe için açının $0^{\circ}$ den $20^{\circ}$ çıkması durumunda maksimum güç $\% 21,62,0^{\circ}$ den 40 ${ }^{\circ}$ çıkması durumunda $\% 40,54,20^{\circ}$ den $40^{\circ}$ ye çıkması durumunda ise $\% 24,14$ azalmıştır.

- $0^{\circ}$ açı için yapay 1 şık kaynağı ve panel arasındaki mesafe 0,8 m'den $1,4 \mathrm{~m}$ ye çıkıldığında elde edilen maksimum güç $\% 25,85$ azalmıştır.

- $20^{\circ}$ açı için yapay 1 şı kaynağ arasındaki mesafe 0,8 m'den $1,4 \mathrm{~m}$ ye çıkıldığında elde edilen maksimum güç $\% 38.08$ azalmıştır.

- $40^{\circ}$ açı için yapay 1 şı kaynağ 1 ve panel arasindaki mesafe 0,8 m'den $1,4 \mathrm{~m}$ ye çıkıldığında elde edilen maksimum güç $\% 48,84$ azalmıştır.

Elde edilen bütün veriler ışığında panel ile yapay 1şık kaynağı arasındaki mesafe ve açı artışı güç oluşumunu olumsuz yönde etkilemektedir. Kısmi gölgeleme konusu güneş tarlalarının projelendirilmesinde dikkat edilmesi gereken çok önemli bir husustur.

\section{Kaynaklar}

Ashouri-Zadeh, A., Toulabi, M., Dobakhshari, A. S., Taghipour-Broujeni, S. and Ranjbar, A. M. (2018). A Novel technique to extract the maximum power of photovoltaic array in partial shading conditions. International Journal of Electrical Power and Energy Systems, 101, 500512, https://doi:10.1016/j.ijepes.2018.03.035.

Bayrak, F., Erturk, G. and Oztop, H. F. (2017). Effects of partial shading on energy and exergy efficiencies for photovoltaic panels. Journal of Cleaner Production, 164, 58-69, https:// doi:10.1016/j.jclepro.2017.06.108.

Chaibi, Y., Malvoni, M., Chouder, A., Boussetta, M. and Salhi, M. (2019). Simple and efficient approach to detect and diagnose electrical faults and partial shading in photovoltaic systems. Energy Conversion and Management, 196, 330-43, https://doi:10.1016/j.enconman.2019.05.086.

Kaced, K., Larbes, C., Ramzan, N., Bounabi, M. and Dahmane, Z. E. (2017). Bat algorithm based maximum power point tracking for photovoltaic system under partial shading conditions. Solar Energy, 158, 490-503, https:// doi:10.1016/j.solener.2017.09.063.

Pareek, S., Chaturvedi, N. and Dahiya, R. (2017). Optimal interconnections to address partial shading losses in solar photovoltaic arrays. Solar Energy, 155, 537-551, https://doi:10.1016/j.solener.2017.06.060.

Ramli, M. Z. and Salam, Z. (2019). Performance evaluation of dc power optimizer (dcpo) for photovoltaic (pv) system during partial shading. Renewable Energy, 139, 1336-1354, https://doi:10.1016/j.renene.2019.02.072.

Sai Krishna, G. and Tukaram M. (2019). Reconfiguration strategies for reducing partial shading effects in photovoltaic arrays: state of the art. Solar Energy, 182, 429-452, https://doi:10.1016/j.solener.2019.02.057.

Sánchez Reinoso, C., Milone, D. H. and Buitrago, R. H. (2013). Simulation of photovoltaic centrals with dynamic shading. Applied Energy, 103, 278-289, https://doi:10.1016/j.apenergy.2012.09.040.

Wang, Y., Wang, D. and Liu, Y. (2017). Study on comprehensive energy-saving of shading and photovoltaics of roof added pv module. Energy Procedia, 132, 598-603, https://doi:10.1016/j.egypro.2017.09.672.

Yin, O. W. and Babu, A. C. (2018). Simple and easy approach for mathematical analysis of photovoltaic (pv) module under normal and partial shading conditions. Optik, 169, 48-61, https://doi:10.1016/j.ijleo.2018.05.037.

Zhang, X., Lau, S. K., Lau, S. S. Y. and Zhao, Y. (2018). Photovoltaic integrated shading devices (pvsds): A Review. Solar Energy, 170, 947-968, https://doi:10.1016/j.solener.2018.05.067.

Zhu, L., Li, Q., Chen, M., Cao, K. and Sun, Y. (2019). A Simplified mathematical model for power output predicting of building integrated photovoltaic under partial shading conditions. Energy Conversion and Management, 180, 831843 , https://doi:10.1016/j.enconman.2018.11.036. 